\title{
The Effects on the Socio-Emotional State of Students in the National Exams in Greece from the Covid-19 Pandemic - Pilot Research
}

\author{
Sousanna-Maria Nikolaou \\ Associate Professor, Department of Primary Education \\ University of Ioannina, Ioannina, Greece
}

\section{Abstract}

The main purpose of this study is to investigate the effects of internment and isolation imposed by the Covid-19 pandemic on the socio-emotional status of students preparing for and taking national exams in July 2020. The main result of the study showed a weakness of consciousness and student stress due mainly to the inadequacy of social relationships, daily social contact with people who managed the same situation highlighting the importance of social capital and socialization in dealing with real life situations. The research found an unprecedented stressful situation of students that manifested itself with a lot of intensity and explosive situations (crying before and after exams, provocative behavior, great anger, disorganization, withdrawal desire, tension, conflicts, physical discomfort, intense anxiety and stress). The research also aims to conduct a scientific discussion of the conclusions regarding the conditions created for young people in the context of internment and isolation from any living communication with their classmates and teachers and the consequences in general in the event that this situation will continue into the next school year, as well as the study of ways in which a similar condition can be avoided in the next phase of the pandemic.

Keywords: Covid-19 pandemic, students, socio-emotional state, exams, Greece

\section{Introduction}

\section{Social status and Covid $\mathbf{- 1 9}$}

The special living condition that developed after the outbreak of Covid-19 around the world necessitated the adaptation to new data in family and personal life as well as in the professional field (Adolph et al., 2020). Regarding the educational process, despite the use of distance education, so as not to lose the child's contact with the educational reality, a number of problems and limitations were identified that were related to the teaching of cognitive subjects and educational inequalities and social capital (friendship social networks) and the social and emotional dimension of learning. The 
emptiness of social relations and the emotional load of the days of internment at home were strong factors to cause problems in the social adjustment and recovery of students, especially those who were preparing for the national exams, but also to reflect on the ways in which they could are supported by teachers through their role as significant others in case we experience a new wave of virus outbreak again from September 2020 (Viner et al., 2020).

Children and adolescents during their stay at home experienced significant changes in multiple levels of their learning and psychosocial development. It is a fact that each person reacts differently to the same situation and each difficulty affects each person differently depending on his psycho-social-emotional state and his behavior. All this new social reality with the main feature of staying and internment at home, the "ban" of socializing, was expected to affect the behavior of people and much more of young teenagers, who rely heavily on social networks and friendships for self-recognition through the acceptance of others, who in fact in view of their entrance exams to university experience on a daily basis great stress and anxiety (Papadimitriou, 2015). They may have disorganization, tension, difficulty concentrating, intense irritability, increased conflict, physical discomfort and may feel intense anxiety, stress, anger manifested by crying (Konstantopoulou et al. 2015). However, it is possible that these reactions are both normal and expected due to the condition they are experiencing. But what if they persist in intensity, frequency, duration and degree and affect the daily life and functionality of the young person? Then the person needs support from special staff to strengthen and promote his mental resilience in order to be able to recover. According to Hadjichristou (2020: 10): "most children and adolescents in the long run will be able to cope psychologically, despite their difficult experiences by developing and / or evolving internal mechanisms for dealing with difficult situations" with the help and support of parents and significant others.

Mental resilience, however, includes an important chapter in social relationships. Friendly social networks, which were severely affected by internment and staying at home, had a significant impact on the young adult's self-confidence and optimism, active participation, values and expectations, and ultimately on his or her mental resilience (Hadjichristou, 2020: 3).

The aim of this pilot study is to record and assess the consequences of the internment and isolation of young adults who were preparing for the national exams by Covid19 , in terms of their socio-emotional status.

\section{The research}

\subsection{Methodology}

\section{Participants}

The pilot research was attended by 12 high school students of the prefecture of Ioannina, 6 girls and 6 boys. In qualitative social research, research subjects are 
deliberately selected in order to serve its objectives. Therefore, neither the participants nor many were random, but were selected to be appropriate for the information sought in order to interpret the subject under consideration (Mantzoukas, 2007). The participating students were selected on the basis of gender (there should be a ratio), based on their evaluation in the first quarter of study (over 18 with an excellent 20) and the relevant scientific field [Humanities, Law and Social Studies (3 students) Technological and Positive Studies (3 students), Health and Life Studies (3 students), Economics and Informatics Studies (3 students), Studies, Positive Sciences (3 students).

\section{Means of data collection}

The data collection tool was the semi-structured interview as the most reliable, because it does not impose a specific context on the interviewee and the researcher using a discussion axis can with appropriate manipulations examine the topic he wants in a way that seems natural and not forced (Nov- Kaltsouni, 2006, 46 et seq .; Robson, 2007). The semi-structured interview consisting of 10 questions was used for data collection.

\section{Interview guide}

For the implementation of the interviews, an interview guide was formed that includes individual questions, which attempt to answer the research questions and produce qualitative data on issues related to social capital, social relationships and the emotional state of the respondents. The interview guide followed the methodology of qualitative research with semistructured interviews. General thematic units and individual questions were constructed, which correspond to the thematic units, while at the same time the researcher had the flexibility to modify them (adaptation or change depending on the data that emerged) (Kyriazi, 2006; Isari $\&$ Pourkos, 2015). Prior to the survey and based on the guide, a pilot survey was conducted on four high school students (who did not participate in the final survey) in order to determine the appropriateness and adequacy of the questions. Pilot research has helped to avoid lengthy and ambiguous responses (Robson, 2007).

According to the objectives set for the qualitative research, the interview guide included 32 questions, which were divided into six thematic sections. Through them we sought the investigation of research questions and the production of quality data, so that the subsequent categorization records in a valid way the data necessary for the research. In the first thematic questions about the ways of communication and their frequency with friends and others before and after the pandemic. In the second the questions referred to the social activities (extracurricular) (type) of the respondents that were suspended or interrupted due to the pandemic. The third topic included questions related to the use of free time in the midst of a pandemic. In the fourth topic the questions referred to the ways of acceptance and reaction in view of the exams. The fifth topic included questions about the shortcomings identified by the respondents themselves during the pandemic and the sixth topic had questions about 
social and friendship networks before the pandemic and in the midst of internment until the exams.

The interview process took place in July 2020 (live and through the use of social media). The interviews were recorded with the consent of the interviewees (Kvale, 2008), were individual and lasted an average of 60 minutes. After the recording, the volume of data was organized, the views were grouped and categorized. The proposal that referred to the subject under consideration was used as a unit of measurement and an inductive system of categories and subcategories of coding the collected data was formed (Bonidis, 2004). The small number of the sample does not allow generalization of the results for the student population that wrote national exams in Greece in 2020.

\section{Analysis of the answers}

The transcripts of the interviews were categorized into sections that had already been formed by the researcher and were enriched by the analysis of the data. The following table describes the categories as they were formed from the processing of the answers and the coding:

Table 1. Categories

\begin{tabular}{|c|c|c|c|c|}
\hline $\begin{array}{l}\text { Means of } \\
\text { Communication }\end{array}$ & Before Internment & $\begin{array}{l}\text { With friends and } \\
\text { classmates }\end{array}$ & $\begin{array}{l}\text { At school } \\
\text { At the tutoring school }\end{array}$ & $\begin{array}{l}12 \\
12 \\
11\end{array}$ \\
\hline & & & $\begin{array}{l}\text { The w/d in the } \\
\text { evenings Afternoon at } \\
\text { leisure }\end{array}$ & 9 \\
\hline & & With teachers & $\begin{array}{l}\text { At school } \\
\text { In meetings in the } \\
\text { afternoons (additional } \\
\text { remedial teaching) }\end{array}$ & $\begin{array}{l}12 \\
9\end{array}$ \\
\hline & After Internment & $\begin{array}{l}\text { With friends and } \\
\text { classmates }\end{array}$ & $\begin{array}{l}\text { Social media } \\
\text { Facebook, Instagram, } \\
\text { Viber (initially every } \\
\text { day and then a few } \\
\text { days before the exams } \\
\text { once a week), phone }\end{array}$ & 12 \\
\hline & & With teachers & $\begin{array}{l}\text { In distance learning a } \\
\text { few hours a week }\end{array}$ & 12 \\
\hline \multirow{2}{*}{$\begin{array}{l}\text { Activities banned } \\
\text { due to the } \\
\text { pandemic }\end{array}$} & Before Internment & $\begin{array}{l}\text { Swimming Volleyball } \\
\text { Basketball Ballet }\end{array}$ & 3-4 times per week & 9 \\
\hline & After Internment & None & - & 12 \\
\hline $\begin{array}{l}\text { Allocation of free } \\
\text { time }\end{array}$ & During Internment & $\begin{array}{l}\text { Social Media (FB, } \\
\text { Instagram...) TV } \\
\text { NETFLIX movies } \\
\text { Hiking with parents }\end{array}$ & $\begin{array}{l}\text { Every day at first and a } \\
\text { few days the exams } \\
\text { rarely }\end{array}$ & 12 \\
\hline
\end{tabular}




\begin{tabular}{|l|l|l|l|l|}
\hline \multirow{2}{*}{$\begin{array}{l}\text { How they reacted } \\
\text { during the exams }\end{array}$} & Before the exams & $\begin{array}{l}\text { Lots of stress, } \\
\text { irritability, depression, } \\
\text { and a lot of crying }\end{array}$ & & 12 \\
\cline { 2 - 5 } & Right after the exams & $\begin{array}{l}\text { Irritation, anxiety, } \\
\text { crying }\end{array}$ & & 11 \\
\hline
\end{tabular}

\subsection{Discussion of the results}

The usual ways of communication of students even those who are eagerly preparing for the national exams and their admission to the University are based on social relationships that have developed in friendly social networks mainly at school. Before being locked up and staying at home, students had daily social interactions with friends and classmates at school, in tutoring, on weekend nights and some even in their free time in the squares and neighborhood meetings. Characteristically they state: "[...] I get away from the stress and reading I have when I meet my friends [...] we were seen every day at school, we talked about our problems and reading [.] but on Saturday afternoon in the square. when we were all with my close ones; I forgot that I was taking national exams". But also important was the social relationship and social interaction on a daily basis at school with their teachers who were directly involved in the issues that occupied the students during the crucial year for them preparing for university admission. They state "[.] we had a very good relationship and communication with our teachers in the core subjects. they were so positive and encouraged. they gave us strength. they explained to us the difficulties. it showed in their behavior and their look that they were anxious with us [.. ] "it encouraged me that the teachers were cool and advised us how to manage our mistakes [. ]". After being locked up at home, the students'

communication with each other and with their friends was initially limited to social media and the telephone, which as they approached the exams became quite limited, while with their teachers it became even more limited to distance learning for a short time. They report features "[...] well that there is both Facebook and Instagram and so we could send a message... of course it does not compare. how long to sit on the computer? We also had parents constantly shouting about using the computer [.]. "We also lost contact with the teachers ... fortunately I also went to a tutoring center and so when we were excluded we did a video conference. but it was not the same".

Students seem to have enough social contact activities in team sports even when preparing for exams which gives them further opportunities to socialize in collective activities. The majority of the sample in their free time participated in groups such as swimming, volleyball, basketball and dance, from which they were excluded due to a pandemic, a fact that was taken very negatively by them. " [..] I lost all my friends from there (sc.swimming) [.] for me swimming was important because I got rid of my daily stress and I had made friends who discussed other topics outside of school ". "With the pandemic I stayed home, no basketball, no friends; complete inactivity ... boring". 
On the contrary, free time was divided into, in their opinion, not so enjoyable activities, which were not comparable to those they had before incarceration, but were solutions of necessity. "What should I do in my free time va I went on FB, Instagram, I sent messages to my friends via Viber [...] at first on a daily basis. "Then I got bored. I felt that there was no point of contact. What else could we say all the same." "I was watching movies on Netflix[.] I was waiting to fill the time [...] at first it seemed perfect, it made me forget. Then I got bored.. if you do not have your friends to talk, to comment [...] what to see [...] It was more pleasant when I went out with my parents

to walk. We introduced them twice a week ". "From one point onwards I was just sitting on the couch [.] complete inactivity [...]. I didn't want to do anything [...]".

All this condition of internment, forced socialization and complete inactivity, which most of the students in our sample seem to have ended up, led to a lack of mental resilience that manifested itself during the exams with behaviors of uncontrollable irritability, anxiety, stress and crying. Features state:

"I was very irritated before and after the exams, even though I had read and written very well [...] I do not know why I was crying all the time [...]" "I was very intense before and after. And to say that I was not read [.] everything else. My stomach ached for days after [...] without any organic cause. I also went to the doctor. "' I was constantly worried. I was also angry ..very angry [...] I could not concentrate on what I was writing, I was generally bored with all this, I mean the exams. On the third day, even though I had written well the previous days, I did not even want to go to write [...] my mother almost dragged me Xa I also took out my anger [...] that is, we also had a conflict [.] that is, how to say I was bored. . no interest".

\section{Discussion of the results}

Social contact, social relationships and peer groups are a very important way of socializing. Peer groups have a special power to socialize and activate (strengthen) key areas of young people's socio-emotional status and mental resilience. Acceptance enhances the child's selfconfidence, develops the ability to communicate with others, to accept boundaries and obligations (Bullen \& Onyx, 1998; Coleman, 1988). In this way he learns to organize his own space and time, gains faith in himself and in personal sources of power, in order to recover from difficulties faster and more effectively. (Nikolaou, 2009; Parsons, 1959; Hadjichristou, 2020, Giavrimis \& Nikolaou, 2020). By participating in groups, children develop the ability to work with people who have the same responsibilities and the same rights and develop initiatives (Bourdieu 1986). The feeling that they are taking responsibility for actions especially strengthens the feeling that they are controlling the situation and gaining calm. This is especially important for children, when they feel involved in school activities, when they participate with daily social contacts in discussions about common problems such as exams (Nikolaou, 2009; Hadjichristou, 2020). 
When students operate in a framework of friendship based on common desires and interests, they shape their self-image and rely on the driving force of values and deeper beliefs with which they make their choices, prioritize their goals, set goals and seek and find ways to make them happen with confidence and consistency (Hadjichristou, 2020: 4 et seq.; Moolenaar et al. 2009: 13-17).

Under these circumstances, any problem or adverse condition of not achieving the goals does not lead the person to behaviors similar to those found in this research process (such as desire to withdraw, difficulty concentrating, tension, stress, intense anxiety, anger, conflict and even physical annoyances), because the person has the power to revise his goals and adjust them, so that he is happy with his life, not to embody the adverse condition and to continue to derive satisfaction and give meaning to his life. The daily communication and social relationships between students and between students and teachers encourage them to realize how important it is for them to believe in themselves and their strengths and to find interest in their lives. All students who take university entrance exams experience intense stress and anxiety, and often embody it, but their social relationships, daily communication and collaboration at school with friends, classmates and teachers are very helpful (Kent et al., 2019).. The results of the research showed that children after a long period of stay at home in the context of significant changes in multiple levels of socialization showed abnormal behaviors (perhaps expected in the unprecedented condition we are experiencing), but showed once again how important is the social contact and the development and maintenance of the living social relations of man. Research in the period of Covid 19 (Giavrimis \& Nikolaou, 2020) on students' social and friendship networks and how they affected students in the midst of a pandemic, found that high social capital can create the right conditions for positive social relationships and interactions of students, for the development of social trust, as a necessary condition for cooperation, productive action and peer behavior. The consequences of the high social capital of students in the pandemic period were particularly positive, emphasizing once again that the development of social and friendly networks and social interaction for the development of initiatives and social trust are key elements of human existence (Almeida et al., 2019; Peng, 2019; Mishra, 2020; Koutra et al., 2020).

\section{Suggestions}

The disease caused by the Covid-19 virus is not over. We still have a long way to go before it can be treated with a vaccine. There is a possibility that the observed behaviors persist in terms of intensity or frequency in the daily life of children. There is also the possibility that in case of internment, banning of social gatherings and finally "de-socialization" in a possible reoutbreak of the pandemic, the same behaviors may be found in higher intensity and in younger students. For these reasons we must reflect and become aware of children and ensure conditions that will prevent such a possible development. It is therefore very important that important 
others, parents and educators, are informed and sensitized to encourage the development of continuous communication in various ways of social groups, even with a redefinition of the way of socialization according to how to access the new data of the youth era information and communication technologies. The conditions that are formed are also influenced by the methods of socialization and that is why it is very important to examine in detail how the factors that play an important role in socialization can be utilized through technology in the best possible way for children to cope by developing internal coping mechanisms the lack of living social contact and the difficult situations involved with the contribution and support of parents and "important" adults.

\section{References}

[1] Adolph, C., Amano, K., Bang-Jensen, B., Fullman, N., \& Wilkerson, J. (2020). Pandemic politics: Timing state-level social distancing responses to COVID19. medRxiv. https://doi.org/10.1101/2020.03.30.20046326।

[2] Almeida, D. J., Byrne, A. M., Smith, R. M., \& Ruiz, S. (2019). How relevant is grit? The importance of social capital in first-generation college students' academic success. Journal of College Student Retention: Research, Theory \& Practice. https://doi.org/10.1177/1521025119854688

[3] Bourdieu, P. (1986) The forms of capital. In J. Richardson (Ed.) Handbook of Theory and Research for the Sociology of Education (pp. 241-258). New York, Greenwood

[4] Bullen, P. \& Onyx, J. (1998). Measuring Social Capital in Five Communities in NSW. http://www.mapl.com.au/a2.htm

[5] Coleman, J. (1988). Social Capital in the Creation of Human Capital., American Journal of Sociology, 94, 95-120.

[6] Giavrimis, P \& Nikolaou, S.M (2020). The Greek University Student's Social Capital during the COVID-19 Pandemic. European Journal of Education 7, (8), pp. 1-16

[7] Hadjichristou, Ch. (2020). Back to school and problems of mental resilience after the result of staying at home during the COVID-19 pandemic Useful tips and activity forms. National and Kapodistrian University of Athens, Psychology department School Psychology Laboratory. Online Available: http://www.centerschoolpsych.psych.uoa.gr (July2, 2020)

[8] Isari, F., \& Pourkos, M. (2015). Qualitative research methodology. [E-book] Athens: Association of Greek Academic Libraries. Retrieved August 15, 2018, from http://hdl.handle.net/ 11419/5826 (in GREEK)

[9] Iosifidis, Th. (2008). Qualitative research methods in the social sciences. Athens: Critique.(in GREEK)

[10] Iosifidis, Th. (2017). Qualitative research methods and epistemology of the social sciences. Thessaloniki: Tziola. (in GREEK)

[11] Kvale, S.(2008). Doing interviews. Sage.

[12] Kent, C., Rechavi, A., \& Rafaeli, S. (2019). The Relationship Between Offline 
Social Capital and Online Learning Interactions. International Journal of Communication, 13, 1186- 1211.

[13] Koutra, K., Roy, A. W., \& Kokaliari, E. D. (2020). The effect of social capital on nonsuicidal self-injury and suicidal behaviors among college students in Greece during the current economic crisis. International Social Work, 63(1), 100-112.

[14] Konstantopoulou, F., Skarvelaki, D. Makrigiannaki, M., Steletou, S., Tzamali, K. \& Andreadakis N. (2015). The stress of evaluation. Panhellenic Conference of Educational Sciences, 721-731. [DOI: http://dx.doi.org/10.12681/edusc.278] (in GREEK)

[15] Mantzoukas S., 2007. Qualitative research in six easy steps: Epistemology, methods and presentation. Nursing, 46 (2), 176-187. (in GREEK)

[16] Bonidis, K. (2004). The content of the textbook as an object of research: a temporal examination of the relevant research and methodological approaches. Athens: Metaichmio (in GREEK)

[17] Mishra, S. (2020). Social networks, social capital, social support and academic success in higher education: A systematic review with a special focus on underrepresented' students. Educational Research Review, 29. https://doi.org/10.1016/j.edurev.2019.100307

[18] Moolenaar, N. M., Daly, A. J., \& Sleegers, P. (2009). Ties with potential: social network structure and innovation in Dutch elementary schools. European Association for Research in Learning and Instruction (EARLI), Amsterdam, August, 25-29.

[19] Nova-Kaltsouni, Ch. (2006). Empirical research methodology in the social sciences. Athens: Gutenberg (in GREEK)

[20] Papadimitriou, G. (2015). The effect of the system of entrance exams in universities on the composition of ABST students. ABST Scientific Yearbook, 10. (in GREEK)

[21] Parson, T. (1959), The school class as a social system: some of its functions in American society, Harvard Educational Review 29,4, 297-318

[22] Peng, M. Y. P. (2019). Testing the mediating role of student learning outcomes in the relationship among students' social capital, international mindsets, and employability. The Asia-Pacific Education Researcher, 28(3), 229-237.

[23] Robson, C. (2007). Real world research. A tool for social scientists and professional researchers. (Dalakou, V., \& Vasilikou, K., translation). Athens: Gutenberg (in GREEK)

[24] Viner, R. M., Russell, S. J., Croker, H., Packer, J., Ward, J., Stansfield, C., Mytton, O., Bonell, C. \& Booy, R. (2020). School closure and management practices during coronavirus outbreaks including COVID-19: a rapid systematic review. The Lancet Child \& Adolescent Health, 4, 397-404. 